\title{
Phenomenon of fatigue among professional drivers in Poland
}

\author{
Agnieszka Buczaj ${ }^{1, A-B, D-F} \oplus$, Anna Pecyna, ${ }^{1, D-F}{ }^{\oplus}$, Monika Krzywicka, ${ }^{1, C} \oplus$, Agnieszka Maruszewska ${ }^{2, D} \oplus$ \\ ${ }^{1}$ University of Life Sciences, Lublin, Poland \\ ${ }^{2}$ Institute of Rural Health, Lublin, Poland \\ A - Research concept and design, B - Collection and/or assembly of data, C - Data analysis and interpretation, \\ $D$ - Writing the article, $E$ - Critical revision of the article, $F$ - Final approval of article
}

Buczaj A, Pecyna A, Krzywicka M, Maruszewska A. Phenomenon of fatigue among professional drivers in Poland. Ann Agric Environ Med. 2021; 28(1): 114-121. doi: 10.26444/aaem/122302

\begin{abstract}
Introduction. Given the specificity of the occupation of professional drivers, fatigue is a very serious problem. Tired drivers can pose a huge threat to themselves and to other users of public roads. The effects of fatigue can lead to loss of drivers' and other users' health or life.

Objective. The aim of the study was to analyze some aspects of fatigue in Polish professional drivers (e.g. symptoms of fatigue reported by drivers, their frequency and number, critical hours, and fatigue management) in relation to such variables as the job seniority, the mode of transport, and the covered distance.

Materials and method. The study involved 398 professional drivers. The method of research based on an anonymous electronic survey.

Results. The survey showed that $89 \%$ of the respondents declared that they suffered from fatigue at work. The most common symptoms of fatigue reported by the drivers included drowsiness (76\% of the respondents), eye strain (67\%), lack of concentration (45\%), and lack of energy (44\%). The mean number of fatigue symptoms indicated by drivers involved in different modes of transport and covering different distances did not differ significantly.

Conclusions. The analysis revealed that the everyday experience of fatigue reported by the surveyed drivers depends on job seniority. There is a significant difference in the occurrence of critical hours experienced by drivers covering different distances.
\end{abstract}

\section{Key words}

fatigue, drivers, work safety

\section{INTRODUCTION}

The phenomenon of fatigue occurs on a daily basis in many workers [1-7]. Formulation of a clear-cut definition of fatigue is quite difficult, as the causes and effects of this phenomenon may vary a great deal. As specified by the international ISO 10075 standard, 'fatigue is a local or systemic nonpathological manifestation of the effects of excessive strain, which is completely reversible with rest' [8]. The basic division distinguishes between the physical fatigue of the muscular system and mental strain, which can prolong the reaction time, decrease the level of alertness, or cause difficulty in processing information. Additionally, sensory fatigue reduces the speed of response to incoming (mainly visual) stimuli, and emotional strain can be imposed on the driver by stress associated with time pressure or dangerous situations on the road [9].

Given the specificity of the occupation, fatigue is a very serious problem in the professional group of drivers. Nowadays, driving a car is associated with the problem of increasingly complex and intensified traffic. This requires the driver's full concentration on the road, which increases fatigue and can greatly enhance the risk of accidents. This in turn may result in loss of the health or death of the vehicle driver or other road users $[9,10]$. One of the most common injuries caused during road accidents is cervical spine trauma [11]. Burnout factors, such as attitudes towards work, physical

Address for correspondence: Anna Pecyna, University of Life Sciences, Lublin, Poland

E-mail: anna.pecyna@up.lublin.pl

Received: 19.12.2019; accepted: 11.05.2020; first published: 27.05.2020 and mental workload, prolonged stress or fatigue, can also cause accidents [12]. There are many causes of driver fatigue. They are associated with the mental and physical status of the driver as well as the organisation of work, road conditions, and many other factors (e.g. noise, vibrations, monotony, and air pollution) [13-22].

Fatigue mainly leads to lack of proper alertness on the road and inability to maintain necessary concentration. There are many symptoms accompanying fatigue reflected in physical ailments or deterioration of the mental state. The most common symptoms include drowsiness, slackened attention, lack of energy, irritability, slow thinking, lack of concentration, headache, lumbar pain, eye strain, nausea, stiffness of shoulders, arm and leg tremor, and the need to lie down $[23,24]$. Fatigue deteriorates such functions as perceptiveness, concentration, speed of reaction, and stability of reaction. It also impairs the ability to process information and has a negative impact on short-term memory [25]. Tired drivers have difficulty in assessing their own abilities and drowsiness occurring together with an increasing feeling of fatigue. Drowsiness significantly reduces the driver's alertness, which results in an 8-fold higher risk of involvement of the driver in road accidents, compared with well-rested drivers. As indicated by statistics, tired drivers who are unable to assess their own level of strength are a cause of approximately $15 \%$ of dangerous road accidents [10].

The most common type of categorization in the research of road accidents refers to the driver's action in terms of causality. One group of road accidents are those caused by the driver involved, while others are those where the 
driver's actions did not contribute to the accident. Research conducted among bus drivers by Dorn and af Wåhlberg indicate that only $44 \%$ of all accidents were considered by the company to be the fault of the bus drivers. The concept of behavioural culpability in the investigation of road accidents is closely connected to the idea of accident proneness and the prediction of accident involvement from individual differences variables [26].

Proper organisation of work is a basic requirement in the prevention of excessive driver fatigue. This problem is regulated by e.g. the Working Time Directive [27], which limits the weekly working time to 48 hours, although it may exceptionally be increased to a maximum of 60 hpours, restricts the length of night work, and forces the taking of rest breaks. The Regulation [28] on the driving times and rest periods (EC 561/2006) introduces rules on the length of driving, breaks and rest periods for professional drivers in both domestic and international transport. The legislation also covers the use of recording devices (tachographs) by virtue of EEC Regulation 3821/85 amended in 1998, on recording devices used in road transport [29]. In turn, Directive 2006/22/EC sets out the minimum levels of enforcement required to ensure compliance with the rules set out in the Regulation on driving and resting times, as well as the use of tachographs [30].

Compliance with the legal regulations should prevent the accumulation of fatigue associated with the extension of working time, shortening the breaks between subsequent drives, and deprivation of sleep [10].

\section{OBJECTIVE}

The aim of the study was to analyze some aspects of fatigue in Polish professional drivers, the symptoms of fatigue reported by drivers, their frequency and number, critical hours, and fatigue management in relation to such variables as job seniority, mode of transport, and covered distance were analyzed.

\section{MATERIALS AND METHOD}

The research was conducted among 398 Polish professional drivers involved in various modes of transport (heavy-load truck transport, light commercial vehicles and passenger transport). The study was carried out in 2018 by an online survey conducted for eight days on the social network sites of Union of Professional Drivers, Polish Professional Drivers on the Route, Passenger Bus Drivers, and Professional Truck Drivers.

The study was based on an anonymous survey conducted using an author-constructed questionnaire. The questionnaire contained 18 questions with a choice of one or more answers providing information on fatigue in professional drivers involved in various modes of transport. The questions were focused on, e.g. the fatigue symptoms indicated by professionals drivers, frequency of occurrence of fatigue symptoms and the perception of 'critical hours'. In addition, the survey concerned prevention of this phenomenon during transport work and methods for management of driver fatigue, as well as respondents' particulars concerning the covered distance by driver, and the demographic characteristics of professional drivers (gender, age, education, time of driving license and job seniority). The survey was created in an electronic form.

The collected material was analyzed using software Statistica ver. 13.1 (Dell Inc.). Basic descriptive statistics were used - numerical and percentage summaries of individual variables. The mean analysis was carried out using the ANOVA with post hoc. Analysis of qualitative variables was carried out using the $\chi 2$ test. The level of significance $\alpha=0.05$ checked whether an indicated fatigue symptom depended on job seniority (Tab. 5), mode of transport (Tab. 7), distance covered (Tab. 9). If $\mathrm{p}<0.05$, then the symptom depends on the job seniority, mode of transport, distance covered.

\section{RESULTS}

Table 1 shows the information about the study group. Women accounted for $9 \%$ of the respondents, professional drivers aged $18-25$ years constituted 35\%, 26-40 year-olds represented $53 \%$, and the group of drivers aged 41 and older accounted for $12 \%$.

$20 \%$ of the respondents had held a driving license for less than 5 years, $39 \%$ from $5-10$ years, and $41 \%$ over 10 years. $52 \%$ of the respondents had been working as a professional driver for less than 5 years, $31 \%$ from $5-10$ years, and $17 \%$ over 10 years. In terms of the mode of transport, $47 \%$ of the drivers (56\% of women, $46 \%$ of men) were involved in heavyload truck transport, $43 \%$ (19\% of women, $45 \%$ of men) drove light commercial vehicles (LCV), and $10 \%$ (25\% of women, $9 \%$ of men) worked in passenger transport.

Table 1. Characteristics of the study group

\begin{tabular}{|c|c|c|c|}
\hline Characteristics & & $\mathbf{N}$ & $\%$ \\
\hline & $\mathrm{F}$ & 36 & 9 \\
\hline \multirow[t]{3}{*}{ Gender } & M & 362 & 91 \\
\hline & Total & 398 & 100 \\
\hline & $18-25$ & 139 & 35 \\
\hline \multirow[t]{3}{*}{ Age (years) } & $26-40$ & 212 & 53 \\
\hline & $41+$ & 47 & 12 \\
\hline & $<5$ & 79 & 20 \\
\hline \multirow[t]{3}{*}{ Time of driving license (years) } & $5-10$ & 155 & 39 \\
\hline & $>11$ & 164 & 41 \\
\hline & Higher education & 70 & 18 \\
\hline \multirow[t]{3}{*}{ Education } & Secondary education & 296 & 74 \\
\hline & Primary education & 32 & 8 \\
\hline & $<5$ & 206 & 52 \\
\hline \multirow[t]{3}{*}{ Job seniority as professional drivers } & $5-10$ & 125 & 31 \\
\hline & $>11$ & 67 & 17 \\
\hline & heavy-loaded truck & 186 & 47 \\
\hline \multirow[t]{2}{*}{ Model of transport } & LCV & 171 & 43 \\
\hline & passenger & 41 & 10 \\
\hline
\end{tabular}

Among the surveyed drivers, $89 \%$ declared that they felt tired at work. Eight hours was the median of driving hours after which the surveyed drivers most often experienced fatigue. The number of driving hours specified by the respondents varied and ranged from $1-24 ; 5 \%$ of the drivers did not indicate a specific number. 
Table 2 presents the responses to question about the frequency of experiencing fatigue according to job seniority. The largest group of drivers experiencing fatigue every day were those who had been working for less than 5 years (51\%). The largest group among drivers experiencing fatigue once a week comprised respondents working for 5-10 years (49\%). The analysis allows the conclusion that the feeling of fatigue is rarely independent of job seniority and ranges from $15 \%-$ $16 \%$ in the individual groups. Analysis of the data $\left(\chi^{2}=7.3\right.$; $\mathrm{p}=0.026)$ revealed that experiencing the feeling of fatigue every day depended on job seniority (Tab. 2).

Table 2. Frequency of fatigue symptoms according to job seniority

Frequency of fatigue

\begin{tabular}{lcccccc} 
Job seniority & $\begin{array}{c}\text { Every day } \\
\mathrm{N}=178\end{array}$ & $\begin{array}{c}\text { Every day } \\
\%\end{array}$ & $\begin{array}{c}\text { One a week } \\
\mathrm{N}=157\end{array}$ & $\begin{array}{c}\text { One a week } \\
\%\end{array}$ & $\begin{array}{c}\text { Rarely } \\
\mathrm{N}=63\end{array}$ & $\begin{array}{c}\text { Rarely } \\
\%\end{array}$ \\
\hline $\begin{array}{l}\text { less than } \\
5 \text { years }\end{array}$ & 105 & 51 & 67 & 33 & 34 & 16 \\
\hline $\begin{array}{l}\text { from } \\
5-10 \text { years }\end{array}$ & 45 & 36 & 61 & 49 & 19 & 15 \\
\hline over 10 years & 28 & 42 & 29 & 43 & 10 & 15
\end{tabular}

The most common fatigue symptoms declared by the respondents included drowsiness (76\% of the respondents), eye strain (67\%), lack of concentration (45\%), and lack of energy (44\%). The professional drivers also reported physical weariness (38\% of the respondents), lumbar pain (30\%), a need to lie down (27\%), irritability (22\%), slow thinking (19\%), headache (12\%), stiffness of shoulders (9\%), slackened attention (7\%), arm and leg tremor, and nausea.

Only $10 \%$ of professional drivers chose 0 or 1 symptom of fatigue. Table 3 presents the number of symptoms of fatigue (from 0 to 13) selected by drivers from the different seniority groups.

Table 3. Number of fatigue symptoms indicated by professional drivers with job seniority

\begin{tabular}{|c|c|c|c|c|c|c|}
\hline \multirow[b]{2}{*}{$\begin{array}{l}\text { Number } \\
\text { of fatigue } \\
\text { symptoms }\end{array}$} & \multicolumn{6}{|c|}{ Job seniority } \\
\hline & $\begin{array}{c}\text { less than } \\
5 \text { years } \\
N=206\end{array}$ & $\begin{array}{c}\text { less than } \\
5 \text { years } \\
\%\end{array}$ & $\begin{array}{l}\text { from } 5- \\
10 \text { years } \\
\mathrm{N}=125\end{array}$ & $\begin{array}{c}\text { from } 5- \\
10 \text { years } \\
\%\end{array}$ & $\begin{array}{c}\text { over } \\
10 \text { years } \\
N=67\end{array}$ & $\begin{array}{c}\text { over } \\
10 \text { years } \\
\%\end{array}$ \\
\hline 0 & 0 & 0 & 0 & 0 & 1 & 1 \\
\hline 1 & 18 & 9 & 6 & 5 & 13 & 19 \\
\hline 2 & 28 & 14 & 8 & 6 & 10 & 15 \\
\hline 3 & 36 & 17 & 34 & 27 & 13 & 19 \\
\hline 4 & 47 & 23 & 35 & 28 & 12 & 18 \\
\hline 5 & 31 & 15 & 16 & 13 & 8 & 12 \\
\hline 6 & 20 & 10 & 11 & 9 & 5 & 7 \\
\hline 7 & 11 & 5 & 7 & 6 & 2 & 3 \\
\hline 8 & 9 & 4 & 3 & 2 & 2 & 3 \\
\hline 9 & 5 & 2 & 4 & 3 & 0 & 0 \\
\hline 10 & 0 & 0 & 0 & 0 & 0 & 0 \\
\hline 11 & 1 & 0 & 0 & 0 & 0 & 0 \\
\hline 12 & 0 & 0 & 1 & 1 & 0 & 0 \\
\hline 13 & 0 & 0 & 0 & 0 & 1 & 1 \\
\hline
\end{tabular}

The average number of fatigue symptoms indicated by the drivers from the different job seniority groups was compared (Tab. 4).
Table 4. Average number of fatigue symptoms from the different job seniority groups

\begin{tabular}{|c|c|c|c|c|}
\hline Job seniority & Mean & $\begin{array}{l}\text { Standard } \\
\text { deviation }\end{array}$ & Mean & $\begin{array}{l}\text { Standard } \\
\text { deviation }\end{array}$ \\
\hline $\begin{array}{l}\text { less than } 5 \text { years } \\
N=206\end{array}$ & 4.13 & 2.02 & \multirow{3}{*}{4.06} & \multirow{3}{*}{2.03} \\
\hline $\begin{array}{l}\text { from } 5-10 \text { years } \\
N=125\end{array}$ & 4.25 & 1.90 & & \\
\hline $\begin{array}{l}\text { over } 10 \text { years } \\
N=67\end{array}$ & 3.48 & 2.22 & & \\
\hline
\end{tabular}

Figure 1 shows an interaction graph. The graph presents the means and confidence intervals. Based on the graph, it can be concluded that one of the means differs significantly from the others as the confidence intervals do not overlap. Drivers with the longest job seniority indicated the lowest number of symptoms.

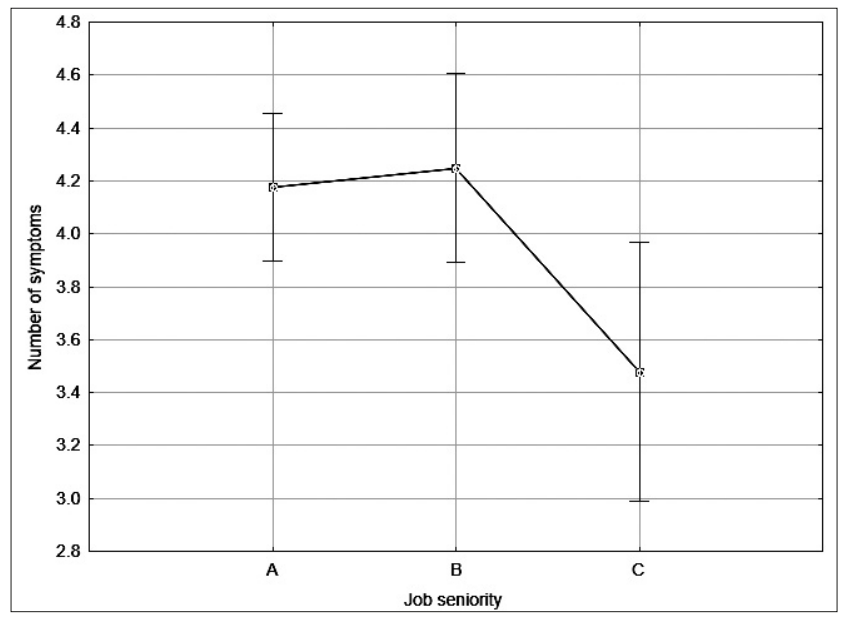

Figure 1. Mean number of fatigue symptoms indicated by professional drivers with job seniority: $\mathrm{A}$ - less than 5 years, $\mathrm{B}$ - from $5-10$ years, $\mathrm{C}$ - more than 10 years

Analysis of variance (ANOVA) showed significant differences in the mean number of fatigue symptoms reported by professional drivers working for less than 5 years, from $5-10$ years, and over 10 years $(\mathrm{p}=0.033$, i.e. $\mathrm{p}<0.05)$.

Two homogeneous groups were obtained from the Scheffé test. The first group includes drivers with job seniority for over 10 years and less than 5 years. The second group includes drivers working less than 5 years and from $5-10$ years. The same result was obtained in the Bonferroni test. One group was obtained from the Tukey test. The same homogeneous groups were obtained from LSD, Newman-Keuls and Duncan tests. The first group included drivers with job seniority less than 5 years and from 5-10 years. The second group included drivers with job seniority over 10 years. Analysis of the graph containing confidence intervals for the average (Fig. 1) confirmed the division into 2 groups. Dunnett's test showed significant differences between the average number of fatigue symptoms reported by drivers working for over 10 years and the remaining averages.

Based on the analysis, it can be concluded that the average number of fatigue symptoms reported by drivers with job seniority over 10 years differs significantly. A similar number of fatigue symptoms are indicated by drivers with job seniority shorter than 5 years and from 5-10 years. 
Table 5 presents fatigue symptoms indicated by professional drivers with different lengths of job seniority. As demonstrated by the $\chi 2$ test, the occurrence of such fatigue symptoms as drowsiness, lack of concentration, irritability, and eye strain depends on job seniority $(\mathrm{p}<0.05)$. Professional drivers with the longest seniority constitute the lowest percentage of respondents that experience these symptoms.

Table 5. Fatigue symptoms vs. job seniority

\begin{tabular}{|c|c|c|c|c|c|c|c|}
\hline \multirow[b]{2}{*}{$\begin{array}{l}\text { Fatigue } \\
\text { symptom }\end{array}$} & \multicolumn{6}{|c|}{ Job seniority } & \multirow[b]{2}{*}{ p level * } \\
\hline & $\begin{array}{c}\text { less } \\
\text { than } 5 \\
\text { years } \\
\mathrm{N}=206\end{array}$ & $\begin{array}{c}\text { less } \\
\text { than } 5 \\
\text { years } \\
\%\end{array}$ & $\begin{array}{c}\text { from } 5 \\
\text { to } 10 \\
\text { years } \\
\mathrm{N}=125\end{array}$ & $\begin{array}{c}\text { from } 5 \\
\text { to } 10 \\
\text { years } \\
\%\end{array}$ & $\begin{array}{c}\text { over } \\
10 \\
\text { years } \\
\mathrm{N}=67\end{array}$ & $\begin{array}{c}\text { over } \\
10 \\
\text { years } \\
\%\end{array}$ & \\
\hline Drowsiness & 167 & 81 & 96 & 77 & 39 & 58 & 0.001 \\
\hline $\begin{array}{l}\text { Lack of } \\
\text { concentration }\end{array}$ & 103 & 50 & 55 & 44 & 20 & 30 & 0.015 \\
\hline Headache & 24 & 12 & 16 & 13 & 6 & 9 & 0.728 \\
\hline $\begin{array}{l}\text { Physical } \\
\text { weariness }\end{array}$ & 77 & 37 & 49 & 39 & 25 & 37 & 0.940 \\
\hline Nausea & 13 & 6 & 2 & 2 & 2 & 3 & 0.103 \\
\hline $\begin{array}{l}\text { Slackened } \\
\text { attention }\end{array}$ & 11 & 5 & 9 & 7 & 4 & 6 & 0.788 \\
\hline Lack of energy & 92 & 45 & 58 & 46 & 26 & 39 & 0.591 \\
\hline Irritability & 43 & 21 & 35 & 28 & 8 & 12 & 0.034 \\
\hline Eye strain & 139 & 67 & 92 & 74 & 35 & 52 & 0.011 \\
\hline $\begin{array}{l}\text { Stiffness of } \\
\text { shoulders }\end{array}$ & 17 & 8 & 11 & 9 & 7 & 10 & 0.860 \\
\hline Lumbar pain & 52 & 25 & 44 & 35 & 21 & 31 & 0.145 \\
\hline $\begin{array}{l}\text { Arm and leg } \\
\text { tremor }\end{array}$ & 8 & 4 & 11 & 9 & 3 & 4 & 0.152 \\
\hline Slow thinking & 42 & 20 & 22 & 18 & 10 & 15 & 0.572 \\
\hline $\begin{array}{l}\text { Need to lie } \\
\text { down }\end{array}$ & 55 & 27 & 28 & 22 & 24 & 36 & 0.135 \\
\hline Other & 5 & 2 & 3 & 2 & 3 & 4 & 0.644 \\
\hline
\end{tabular}

* $p$ values $p<0.05$ were considered statistically significant.

Table 6 shows comparison of the average number of fatigue symptoms indicated by drivers involved in the different modes of transport.

Table 6. Average number of fatigue symptoms indicated by drivers involved in the different modes of transport

\begin{tabular}{|c|c|c|c|c|}
\hline Modes of transport & Mean & $\begin{array}{l}\text { Standard } \\
\text { deviation }\end{array}$ & Mean & $\begin{array}{l}\text { Standard } \\
\text { deviation }\end{array}$ \\
\hline $\begin{array}{l}\text { heavy-load truck transport } \\
\mathrm{N}=186\end{array}$ & 4.06 & 2.19 & \multirow{3}{*}{4.06} & \multirow{3}{*}{2.03} \\
\hline $\begin{array}{l}\text { light commercial vehicle transport } \\
\mathrm{N}=171\end{array}$ & 4.13 & 1.94 & & \\
\hline $\begin{array}{l}\text { passenger transport } \\
\mathrm{N}=41\end{array}$ & 3.73 & 1.61 & & \\
\hline
\end{tabular}

Figure 2 (interaction graph) presents the means and confidence intervals. Based on the graph, it can be concluded that the means do not differ significantly from each other.

As revealed by the analysis of variance (ANOVA), the average numbers of fatigue symptoms indicated by professional drivers involved in the different modes of transport do not differ significantly $(p=0.53$, i.e. $p>0.05)$. Table 7 presents fatigue symptoms reported by the professional drivers working in the different modes of transport. The $\chi^{2}$ test indicated that the occurrence of such fatigue symptoms as lack of concentration, physical weariness, nausea, slackened attention, lack of energy, irritability, eye strain, stiffness of

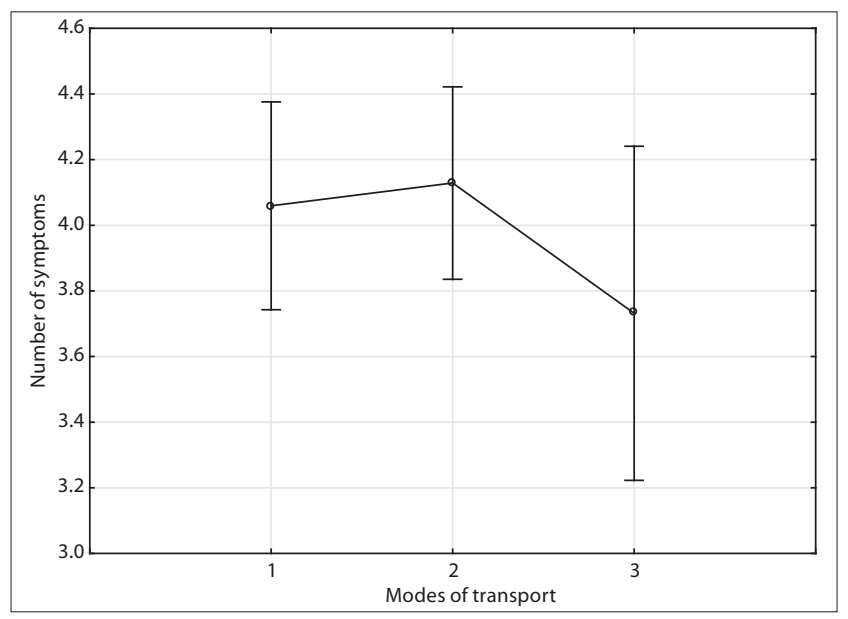

Figure 2. Mean number of fatigue symptoms indicated by professional drivers transporting goods in heavy-load trucks: (1), goods in light commercial vehicles (2), and passengers (3)

shoulders, lumbar pain, arm and leg tremor, slow thinking, and a need to lie down, did not depend on the mode of transport $(\mathrm{p}>0.05)$. The lowest percentage of professional drivers who experienced drowsiness was represented by workers of passenger transport. The lowest percentage of occurrence of headaches was reported by the group of LCV drivers. The heavy-load truck drivers reported the smallest percentage of occurrence of other symptoms.

The mean number of fatigue symptoms indicated by drivers covering various distances was compared (Tab. 8). The analysis involved a group of 393 drivers, as the other 5 respondents did not provide relevant data. The drivers represented the following groups based on the distance range: up to $749 \mathrm{~km} /$ week - $4 \%$ of the respondents, $750-1,499 \mathrm{~km} /$ week - 8\%, 1,500-2,249 km/week - 12\%, 2,250-2,999 km/week - 17\%, 3,000-3,749 km/week - 24\%, $3,750-4,499 \mathrm{~km} /$ week - 11\%, 4,500-5,249 km/week - 13\%, $5,250-5,999 \mathrm{~km} /$ week $-2 \%$, and at least $6,000 \mathrm{~km} /$ week $9 \%$. The median of the distance covered at work per week was $3,000 \mathrm{~km}$.

Figure 3 (interaction graph) presents the means and confidence intervals and indicates that the mean numbers of symptoms do not differ significantly.

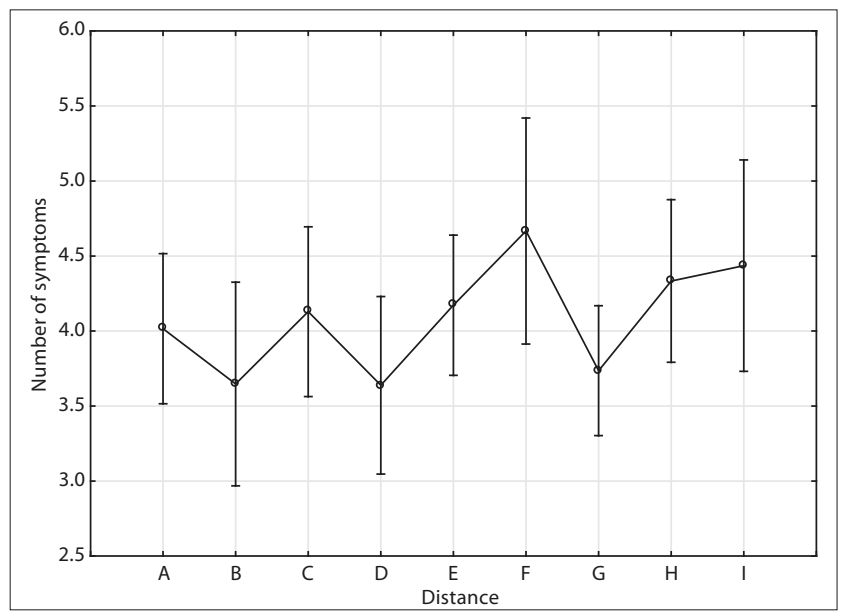

Figure 3. Mean number of fatigue symptoms indicated by professional drivers covering different distances per week: up to $749 \mathrm{~km}(\mathrm{~A}) ; 750-1,499 \mathrm{~km}(\mathrm{~B}) ; 1,500-$ 2,249 km (C); 2250-2999 km (D); 3,000-3,749 km (E); 3,750-4,499 km (F); 4,500$5,249 \mathrm{~km}(\mathrm{G}) ; 5,250-5,999 \mathrm{~km}(\mathrm{H}) ;$ at least $6,000 \mathrm{~km}(\mathrm{I})$ 
Table 7. Fatigue symptoms reported by professional drivers vs. mode of transport

\begin{tabular}{|c|c|c|c|c|c|c|c|}
\hline \multirow[b]{2}{*}{ Fatigue symptom } & \multicolumn{6}{|c|}{ Mode of transport } & \multirow[b]{2}{*}{ P level * } \\
\hline & $\begin{array}{l}\text { heavy-loaded truck } \\
\text { transport } \\
\mathrm{N}=186\end{array}$ & $\begin{array}{c}\text { heavy-load truck } \\
\text { transport } \\
\%\end{array}$ & $\begin{array}{l}\text { light commercial } \\
\text { vehicle transport } \\
\qquad \mathrm{N}=171\end{array}$ & $\begin{array}{c}\text { light commercial } \\
\text { vehicle transport } \\
\qquad \%\end{array}$ & $\begin{array}{c}\text { passenger } \\
\text { transport } \\
\mathrm{N}=41\end{array}$ & $\begin{array}{c}\text { passenger } \\
\text { transport } \\
\%\end{array}$ & \\
\hline Drowsiness & 146 & 78 & 132 & 77 & 24 & 59 & 0.022 \\
\hline Lack of concentration & 83 & 45 & 81 & 47 & 14 & 34 & 0.310 \\
\hline Headache & 22 & 12 & 14 & 8 & 10 & 24 & 0.014 \\
\hline Physical weariness & 65 & 35 & 68 & 40 & 18 & 44 & 0.456 \\
\hline Nausea & 8 & 4 & 7 & 4 & 2 & 5 & 0.975 \\
\hline Slackened attention & 14 & 8 & 8 & 5 & 4 & 10 & 0.375 \\
\hline Lack of energy & 82 & 44 & 82 & 48 & 12 & 29 & 0.096 \\
\hline Irritability & 35 & 19 & 41 & 24 & 10 & 24 & 0.447 \\
\hline Eye strain & 122 & 66 & 116 & 68 & 29 & 71 & 0.787 \\
\hline Lumbar pain & 55 & 30 & 52 & 30 & 10 & 24 & 0.747 \\
\hline Arm and leg tremor & 11 & 6 & 10 & 6 & 1 & 2 & 0.658 \\
\hline Slow thinking & 34 & 18 & 31 & 18 & 9 & 22 & 0.843 \\
\hline Need to lie down & 58 & 31 & 43 & 25 & 6 & 15 & 0.076 \\
\hline Other & 1 & 1 & 9 & 6 & 1 & 2 & 0.024 \\
\hline
\end{tabular}

${ }^{*} p$ values $p<0.05$ were considered statistically significant

Table 8. Mean number of fatigue symptoms indicated by drivers covering various distances

\begin{tabular}{|c|c|c|c|c|}
\hline Distance $[\mathrm{km} /$ week] & Mean & Standard deviation & Mean & Standard deviation \\
\hline $\begin{array}{l}\text { up to } 749 \\
\mathrm{~N}=17\end{array}$ & 3.65 & 1.32 & & \\
\hline $\begin{array}{l}750-1,499 \\
N=31\end{array}$ & 4.13 & 1.54 & & \\
\hline $\begin{array}{l}1,500-2,249 \\
N=47\end{array}$ & 3.64 & 2.02 & & \\
\hline $\begin{array}{l}2,250-2,999 \\
N=65\end{array}$ & 4.02 & 2.02 & & \\
\hline $\begin{array}{l}3,000-3,749 \\
N=93\end{array}$ & 4.17 & 2.27 & 4.08 & 2.03 \\
\hline $\begin{array}{l}3,750-4,499 \\
N=42\end{array}$ & 4.67 & 2.42 & & \\
\hline $\begin{array}{l}4,500-5,249 \\
N=53\end{array}$ & 3.74 & 1.57 & & \\
\hline $\begin{array}{l}5,250-5,999 \\
N=6\end{array}$ & 4.33 & 0.52 & & \\
\hline $\begin{array}{l}\text { from } 6,000 \\
N=39\end{array}$ & 4.44 & 2.17 & & \\
\hline
\end{tabular}

As demonstrated by the analysis of variance (ANOVA), the mean numbers of fatigue symptoms indicated by the professional drivers covering different distances did not differ significantly ( $p=0.29$, i.e. $p>0.05$ ). Table 9 presents symptoms indicated by the professional drivers in groups covering various distances. The $\chi 2$ test demonstrated that the development of headaches was related to the distances covered by the respondents $(\mathrm{p}<0.05)$. The largest percentage of professional drivers suffering from headaches was represented by drivers covering the shortest distances (up to $750 \mathrm{~km} /$ week).

While driving, $81 \%$ of the respondents were affected by 'critical hours'. This depended on the time spent behind the wheel according to $32 \%$ of the respondents, time of day - indicated by $62 \%$, and other factors - declared by $6 \%$. The other factors included the weather, stress, frame of mind, and the possibility of sufficient rest and sleep before driving. As shown by the respondents, 'critical hours' are usually experienced at night (68\% of respondents), during the last hours of driving (19\%), and during the first hours of driving (5\%). The answer 'other' was indicated by $8 \%$ of the drivers. 'Critical hours' were experienced by $80 \%$ of respondents working less than 5 years, $85 \%$ of the group working from 5-10 years, and 76\% of drivers with over 10year seniority. As demonstrated by the analysis, experiencing 'critical hours' did not depend on job seniority $(\chi 2=2.3$; $p$ $=0.32$ ).

As indicated by $98 \%$ of the respondents, driver fatigue is associated with road conditions. $85 \%$ of the surveyed drivers believed that the monotony of driving increases fatigue. As suggested by $77 \%$ of the respondents, express roads enhance the monotony of driving.

Analysis of the perception of 'critical hours' in relation to distances covered by the surveyed drivers showed a significant difference between the average distances covered per week by drivers who experience 'critical hours', and those who do not report this problem. The latter drivers cover a distance of $\sim 2,520 \mathrm{~km} /$ week and the former respondents drove for $\sim 3,654 \mathrm{~km} /$ week (U Mann-Whitney test $\mathrm{p}=0.00004$ and Wald-Wolfowitz test $\mathrm{p}=0.0000003$ ).

Professional drivers most often coped with fatigue by drinking coffee or energy drinks, eating snacks, and taking a break for a nap or a walk (Fig. 4). 
Table 9. Fatigue symptoms reported by professional drivers in relation to the different distances covered

\begin{tabular}{|c|c|c|c|c|c|c|c|c|c|c|}
\hline \multirow[b]{2}{*}{ Fatigue symptom } & \multicolumn{9}{|c|}{ Distance $[\mathrm{km} /$ week] } & \multirow[b]{2}{*}{ p level } \\
\hline & $\begin{array}{c}\text { up to } 749 \\
\mathrm{~N}=17\end{array}$ & $\begin{array}{c}750-1,499 \\
N=31\end{array}$ & $\begin{array}{c}, 500-2,249 \\
N=47\end{array}$ & $\begin{array}{c}2,250-2,999 \\
N=65\end{array}$ & $\begin{array}{c}3,000-3,749 \\
N=93\end{array}$ & $\begin{array}{c}3,750-4,499 \\
N=42\end{array}$ & $\begin{array}{c}4,500-5,249 \\
N=53\end{array}$ & $\begin{array}{c}5,250-5,999 \\
N=6\end{array}$ & $\begin{array}{c}\text { from } 6,000 \\
\qquad N=39\end{array}$ & \\
\hline Lack of concentration & $5(29 \%)$ & $16(52 \%)$ & $22(47 \%)$ & $31(48 \%)$ & $42(45 \%)$ & $16(38 \%)$ & $26(49 \%)$ & $2(33 \%)$ & $17(44 \%)$ & 0.858 \\
\hline Headache & $7(41 \%)$ & $4(13 \%)$ & $8(17 \%)$ & $8(12 \%)$ & $7(8 \%)$ & $4(10 \%)$ & $1(2 \%)$ & $0(0 \%)$ & $7(18 \%)$ & 0.002 \\
\hline Nausea & $1(6 \%)$ & $0(0 \%)$ & $0(0 \%)$ & $2(3 \%)$ & $6(6 \%)$ & $3(7 \%)$ & $0(0 \%)$ & $0(0 \%)$ & $5(13 \%)$ & 0.056 \\
\hline Slackened attention & $1(6 \%)$ & $2(6 \%)$ & $1(2 \%)$ & $5(8 \%)$ & $8(9 \%)$ & $3(7 \%)$ & $1(2 \%)$ & $0(0 \%)$ & $3(8 \%)$ & 0.770 \\
\hline Lack of energy & $6(35 \%)$ & $14(45 \%)$ & $17(36 \%)$ & $29(45 \%)$ & $38(41 \%)$ & 19 (45\%) & $29(55 \%)$ & $2(33 \%)$ & $20(51 \%)$ & 0.682 \\
\hline Irritability & $2(12 \%)$ & $7(23 \%)$ & $8(17 \%)$ & $13(20 \%)$ & $18(19 \%)$ & $13(31 \%)$ & $12(23 \%)$ & $3(50 \%)$ & $10(26 \%)$ & 0.505 \\
\hline Eye strain & $11(65 \%)$ & $19(61 \%)$ & $30(64 \%)$ & $42(65 \%)$ & $62(67 \%)$ & $29(69 \%)$ & $35(66 \%)$ & $5(83 \%)$ & $30(77 \%)$ & 0.904 \\
\hline Stiffness of shoulders & $2(12 \%)$ & $5(16 \%)$ & $3(6 \%)$ & $4(6 \%)$ & $11(12 \%)$ & $5(12 \%)$ & $1(2 \%)$ & $1(17 \%)$ & $3(8 \%)$ & 0.403 \\
\hline Lumbar pain & $6(35 \%)$ & $9(29 \%)$ & $12(26 \%)$ & $22(34 \%)$ & $27(29 \%)$ & $16(38 \%)$ & $13(25 \%)$ & $2(33 \%)$ & $10(26 \%)$ & 0.888 \\
\hline Arm and leg tremor & $0(0 \%)$ & $1(3 \%)$ & $0(0 \%)$ & $4(6 \%)$ & $7(8 \%)$ & $2(5 \%)$ & $4(8 \%)$ & $2(33 \%)$ & $2(5 \%)$ & 0.082 \\
\hline Slow thinking & $2(12 \%)$ & $8(26 \%)$ & $6(13 \%)$ & $8(12 \%)$ & $25(27 \%)$ & $10(24 \%)$ & $7(13 \%)$ & $1(17 \%)$ & $7(18 \%)$ & 0.248 \\
\hline Need to lie down & $2(12 \%)$ & $11(35 \%)$ & $11(23 \%)$ & $16(25 \%)$ & $34(37 \%)$ & $15(36 \%)$ & $10(19 \%)$ & $1(17 \%)$ & $7(18 \%)$ & 0.105 \\
\hline Other & $0(0 \%)$ & $1(3 \%)$ & $2(4 \%)$ & $0(0 \%)$ & $2(2 \%)$ & $2(5 \%)$ & $2(4 \%)$ & $0(0 \%)$ & $2(5 \%)$ & 0.797 \\
\hline
\end{tabular}

${ }^{*} p$ values $p<0.05$ were considered statistically significant.

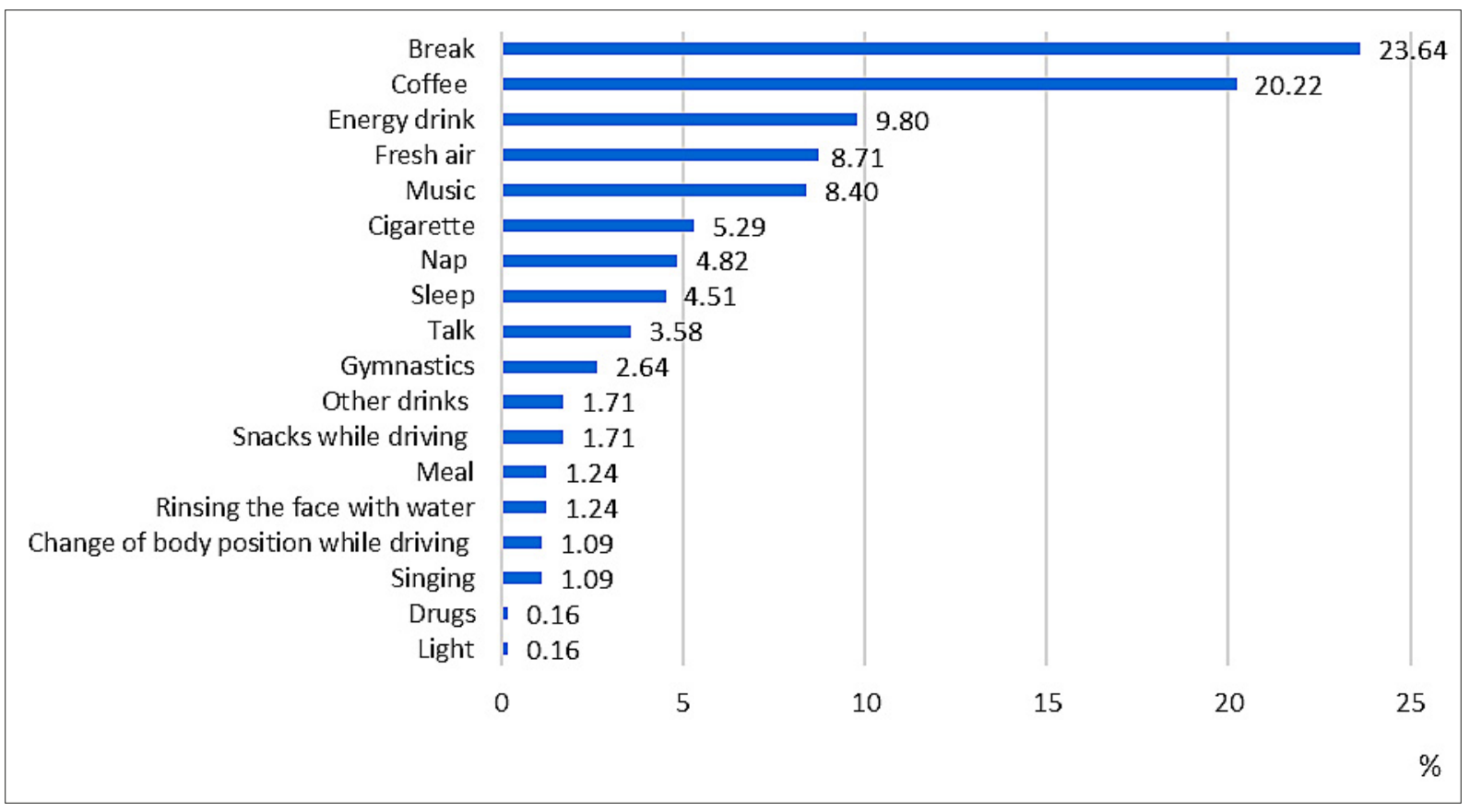

Figure 4. Frequency of different methods for management of driver fatigue

\section{DISCUSSION}

Driver fatigue is the cause of $1-3 \%$ of road accidents, and even $20-30 \%$ on major roads and motorways $[31,32]$. Fatigue affects mental alertness, causing drowsiness which slows down reaction time, reduces consciousness and weakens judgment, thereby reducing the individual's ability to drive safely and increasing the risk of human error, which can lead to injuries and fatalities $[16,24,32,33]$.

In relation to the most frequently reported symptoms of fatigue by the tested drivers, similar results were reported by Lasota and Hankiewicz, who surveyed truck drivers and van drivers in courier companies. The respondents most often complained of drowsiness, yawning, eye strain, and a need to lie down $[14,15]$. In the analysis, the occurrence of fatigue symptoms reported by the drivers did not depend on the mode of transport. Research conducted by Jackson et al. showed that drowsy drivers took longer to react, were less attentive to their environment, and had impaired decisionmaking skills [19].

The method for reducing the number of accidents associated with fatigue is to avoid driving by those that have not slept and rested sufficiently. Insufficient hours of sleep predict truck drivers' fatigue while driving $[16,17]$. Drivers who slept 
less during the last sleep stage over the last 24 hours, and who experienced segmented sleep, were found to be more likely to be involved in fatigue-related accidents. As reported by Hanowski et al. (2007), drivers who had less sleep than usual before driving were at greater risk of accidents, failure, or conflicts associated with failure [34].

According to the majority of the surveyed drivers, their fatigue is affected by road conditions. The monotony of driving and the highway affect increasing driver fatigue. Research Larue shows that during a monotonous driving task, two dimensions of monotony, namely the road design monotony and roadside variability, can lead to a rapid decrement of the alertness of the driver [18].

As shown in the current study, professional drivers usually cope with fatigue by, e.g. drinking coffee and energy drinks, eating snacks, or taking a break for a nap or a walk.

Professional drivers in the research conducted by Kupiec [35] as a way of coping with fatigue most often indicated stimulants (coffee, energy drinks, cigarettes), sleep and other ways (e.g. loud music, cold air, opening the window), and much less frequently for activity, snacks and napping. In contrast, in researches by Gershon et al., the most common way of dealing with fatigue by groups of professional and non-professional drivers was listening to the radio [36].

Research by Friswell and Williamson showed that the most commonly used strategies for light commercial drivers were those that could be employed while driving, such as music, ventilation, eating while driving and caffeine-containing drinks. Heavy load drivers, on the other hand, were most likely to use stopping to nap or rest in addition to the onroad strategies of music, ventilation and caffeine drinks [37].

Findings by Ünal et al. suggest that when engaged with monotonous driving tasks, listening to music might be a good strategy to counter boredom and to satisfy the need for arousal [38]. Other preventive measures characterised by some effectiveness in the temporary suppression of drowsiness indicated by the respondents include a short nap. This is associated with the reduction of subjective sleepiness, better performance of tasks, and suppression of slow eye movements. Effective napping may well reduce the number of motor vehicle accidents related to fatigue [39].

The most frequently used countermeasures reported by truck drivers were stopping the vehicle and exercising, opening the windows, and washing the face. In terms of the perceived effectiveness, truck drivers reported that taking a short nap, stopping the vehicle and exercising, and washing the face were the most effective countermeasures. Taxi drivers perceived stopping the vehicle and exercising, opening the window, and taking a short nap to be the most effective methods [17].

Listening to the radio and opening the window were the most frequently used and also perceived as highly effective coping behaviours by non-professional and professional drivers alike. Professional drivers counteract fatigue also at the strategic/planning level of driving, and use a much larger repertoire of coping-behaviours - planning rest stops ahead, stopping for a short nap and drinking coffee [36].

Caffeinated substances can significantly protect against accident risk for the long distance commercial driver and has important implications for the improvement of fatigue management. Sharwood showed that drivers who consumed caffeinated substances for this purpose had a $63 \%$ reduced likelihood of an accident [40]. However, it turns out that drinking coffee after a meal can be unfavorable, especially if the meal was greasy [41].

Driving time also had a significant effect on the subjective fatigue and driving performance measures among the three groups. A certain amount of rest time can eliminate the negative effects of fatigue. The results of this study show that both the driving time and the rest time have significant effects on driving performance and driver recovery [21].

An important factor affecting the driver's ability to focus throughout the journey is the air quality in the vehicle's cabin [42], and in Makowiec's opinion, climate conditions can modify the drivers fatigue [20].

Research by Ucińska et al. additionally indicates a relationship between the feeling of fatigue and the personality and temperament traits of the driver [43].

In a study of Meng at al., professional drivers manage their own fatigue with methods that have little effect on actually counteracting fatigue. Future education should make efforts to publicize the effectiveness of different fatigue countermeasures and encourage drivers to stop and take a nap when they feel fatigue [17].

In addition, in research conducted by Cardoso et al., it was found that muscle fatigue was more pronounced in a standard industry chair. Maintaining the right posture can be the key to delaying fatigue during a long-term driving task. The new ergonomic chair can be a solution that increases road safety and reduces the number of vehicle accidents related to fatigue [44].

Currently, various technologies have been developed to prevent accidents caused by drowsy drivers; for example, detection technologies use in-vehicle devices to sense changes in the driver that indicate sleepiness, such as excessive eyelid closure and head-nodding, the use of rumble strips (shoulder or cenrtre line), in-vehicle lane departure warning systems, and collision avoidance systems [45].

\section{CONCLUSIONS}

Analysis of some aspects of fatigue experienced by Polish professional drivers demonstrated that the everyday recurrence of the phenomenon depends on their job seniority. Every day fatigue was reported least often by drivers with the longest seniority. In addition, drivers with the longest seniority indicated the least number of fatigue symptoms. Drivers with the longest seniority were the least likely to develop such symptoms as drowsiness, lack of concentration, irritability, or eye strain.

In turn, the mean number of fatigue symptoms affecting drivers involved in different modes of transport and covering different distances did not differ significantly.

However, there was a significant difference in the perception of 'critical hours' by drivers covering different distances. The distance was found to be associated with the occurrence of headaches, i.e. a symptom that was most frequently indicated by drivers covering the shortest distances (up to $750 \mathrm{~km} /$ week). It was found that the perception of 'critical hours' did not depend on job seniority. 


\section{REFERENCES}

1. Tang C, Liu C, Fang P,Xiang Y, Min R. Work-Related Accumulated Fatigue among Doctors in Tertiary Hospitals: A Cross-Sectional Survey in Six Provinces of China. Int J Environ Res Public Health. 2019; 16(17): 3049

2. Han K, Trinkoff AM, Geiger-Brown J. Factors Associated with WorkRelated Fatigue and Recovery in Hospital Nurses Working 12-Hour Shifts. Workplace Health \& Safety. 2014; 62(10): 409-414.

3. Singal R. Variations of Mental Fatigue on Inspectors in Automobile Industry During Evening Shift - A Case study of Maruti Suzuki India Limited, Gurgaon. Int J Latest Trends Engineering Technol (IJLTET) 2015; 5(4): 429-435.

4. Aryal A, Ghahramani A, Becerik-Gerber B. Monitoring fatigue in construction workers using physiological measurements. Automat Constr. 2017; 82: 154-165.

5. Levenson A. Workplace fatigue is a systems problem. Cons Psychol J Pract Res. 2017; 69(2): 130-142.

6. Hystad SW, Saus ER, Sætrevik B, Eid J. Fatigue in seafarers working in the offshore oil and gas re-supply industry: effects of safety climate, psychosocial work environment and shift arrangement. Int Marit Health. 2013; 64(2): 72-79.

7. Filon F, Drusian A, Ronchese F, Negro C. Video Display Operator Complaints: A 10-Year Follow-Up of Visual Fatigue and Refractive Disorders. Int J Environ Res Public Health. 2019; 16 (14): 2501.

8. PN-EN ISO 10075-1:2018-01. Standard: Ergonomic rules regarding mental work load - Part 1: General issues and concepts, terms and definitions.

9. Bąk J, Bąk-Gajda D. Selected psychological factors affecting the driver's reaction time. Scientific Papers of the Institute of Vehicle 2013; 5(96) 21-29. (in Polish)

10. Makowiec-Dąbrowska T, Bartkiewicz A, Siedlecka J, Gadzicka E. The effect of fatigue on the ability to drive vehicles. Med Pr. 2011; 62(3): 281-290. (in Polish)

11. Wiszniewski R, Gorgone Ch. Characteristics of medical procedures performed by firefighters. Crit Care Innov. 2019; 2(4): 17-24.

12. Leszczyński P, Panczyk M, Podgórski M, Owczarek K, Gałązkowski R, Mikos M, Charuta A, Zacharuk T, Gotlib J. Determinants of occupational burnout among employees of the Emergency Medical Services in Poland. Ann Agr Env Med. 2019; 26(1): 114-119.

13. Sasin P, Cieślak W. Safety of drivers in road transport - occupational risk. In: Education for safety. Ed. Wysocka EK. Publisher University of Safety in Poznań, Polska, 2014; 111-114. (in Polish)

14. Lasota AM, Hankiewicz K. Fatigue of truck drivers in courier companies. Logistics 2015; 4: 4422-4428. (in Polish)

15. Lasota A, Hankiewicz K. Fatigue of van drivers in courier companies. Logistics 2015; 3: 5704-5708. (in Polish)

16. Gonçalves M, Amici R, Lucas R, Åkerstedt T, Cirignotta F, Horne J, Léger D, McNicholas WT, Partinen M, Téran-Santos J, Peigneux P, Grote L, \& National Representatives as Study Collaborators. Sleepiness at the wheel across Europe: A survey of 19 countries. J Sleep Res. 2015 24(3): 242-253.

17. Meng F, Li S, Cao L, Li M, Peng Q, Wang C, Zhang W. Driving Fatigue in Professional Drivers: A Survey of Truck and Taxi Drivers. Traffic Injury Prevention. 2015; 16(5): 474-483.

18. Larue GS, Rakotonirainy A, Pettitt AN. Driving performance impairments due to hypovigilance on monotonous roads. Accid Anal Prev. 2011; 43(6): 2037-2046.

19. Jackson ML, Croft RJ, Kennedy GA, Owens K, Howard ME. Cognitive components of simulated driving performance: sleep loss effects and predictors. Accid Anal Prev. 2013; 50: 438-44.

20. Makowiec-Dąbrowska T, Gadzicka E, Siedlecka J, Szyjkowska A, Viebig P, Kozak P, Bortkiewicz A. Climate conditions and work-related fatigue among professional drivers. Int J Biometeorol. 2019; 63: 121-128.

21. Wang L, Pei Y. The Impact of continuous driving time and ret time on commercial drivers' driving performance and recovery. J Safety Res. 2014; 50: 11-15.

22. Phillips RO, Sagberg F. Road accidents caused by sleepy drivers: Update of a Norwegian survey. Accid Anal Prev. 2013; 50: 138-146.
23. Santos JA, Lu JL. Occupational safety conditions of bus drivers in Metro Manila, the Philippines. Int J Occup Saf Ergon. 2016; 22(4): 508-513.

24. Rosso GL1, Perotto M, Feola M, Caramella M. Falling asleep at the wheel among Italian professional drivers (PDs): results from the HiRis PD study. Int J Occup Med Environ Health. 2014; 27(6): 1005-12.

25. Gembalska-Kwiecień A. States of man affecting his reliability. Assistance systems in production engineering. Engineering of Technical Systems. 2016; 2(4): 131-136.

26. Dorn L. af Wåhlberg AE. Behavioral culpability for traffic accidents. Transport Res F - Traf. 2019; 60: 505-514.

27. Directive 2002/15/EC of the European Parliament and of the Council of 11 March 2002 on the organisation of the working time of persons performing mobile road transport activities.

28. Regulation (EC) No 561/2006 of the European Parliament and of the Council of 15 March 2006 on the harmonisation of certain social legislation relating to road transport and amending Council Regulations (EEC) No 3821/85 and (EC) No 2135/98 and repealing Council Regulation (EEC) No 3820/85 (Text with EEA relevance) Declaration.

29. Council Regulation (EEC) No 3821/85 of 20 December 1985 on recording equipment in road transport.

30. Directive 2006/22/EC of the European Parliament and of the Council of 15 March 2006 on minimum conditions for the implementation of Council Regulations (EEC) No 3820/85 and (EEC) No 3821/85 concerning social legislation relating to road transport activities and repealing Council Directive 88/599/EEC (Text with EEA relevance) - Declarations.

31. Jamroz K, Smolarek L. Driver Fatigue and Road Safety on Poland's National Roads. Int J of Occup Saf Ergo. 2013; 19(2): 297-309.

32. Williamson A, Lombardi DA, Folkard S, Stutts J, Courtney TK, Connor JL. The link between fatigue and safety. Accid Anal Prev. 2011; 43(2): $498-515$.

33. Chen T, Sze NN, Bai L. Safety of professional drivers in an ageing society - A driving simulator study. Transport Res F-Traf. 2019; 67: 101-112.

34. Hanowski RJ, Hickman J, Fumero MC, Olson RL, Dingus TA. The sleep of commercial vehicle drivers under the 2003 hours-of-service regulations. Accident Anal Prev. 2007; 39: 1140-1145.

35. Kupiec A, Kupiec J. Przyczyny, skutki i metody zapobiegania zmęczeniu kierowcy. Autobusy 2017; 12: 264-270. (in Polish)

36. Gershon P, Shinar D, Oron-Gilad T, Parmet Y, Ronen A. Usage and perceived effectiveness of fatigue countermeasures for professional and nonprofessional drivers. Accid Anal Prev. 2011; 43: 797-803.

37. Friswell R, Williamson A. Comparison of the fatigue experiences of short haul light and long distance heavy vehicle drivers. Safety Science. 2013; 57: 203-213.

38. Ünal AB, de Waard D, Epstude K, Steg L. Driving with music: Effects on arousal and performance. Transport Res F-Traf. 2013; 21: 52-65.

39. Hayahsi M, Abe A. Short daytime naps in a car seat to counteract daytime sleepiness: The effect of backrest angl. Sleep Biol Rhythms. 2008; 6: 34-41.

40. Sharwood LN, Elkington J, Meuleners L, Ivers R, Boufous S, Stevenson M. Use of caffeinated substances and risk of crashes in long distance drivers of commercial vehicles: case-control study. BMJ. 2013; 346: f1140.

41. Makowiec-Dąbrowska T, Siedlecka J, Gadzicka E, Szyjkowska A, Dania M, Viebig P, Kosobudzki M, Bortkiewicz A. Zmęczenie pracą u kierowców autobusów miejskich. Med Pr. 2015; 66(5): 661-677. (in Polish)

42. Fouzi MSM, Othoman MA, Sulaiman SA. Effect of Recirculation on Air Quality in a Car Compartment. Aust J Basic \& Appl Sci. 2014; 8(4): 466-470.

43. Ucińska M, Odachowska E, Gąsiorek K. Znaczenie temperamentu w analizie zmęczenia i jego skutków na przykładzie kierowców taxi. Autobusy 2016; 12: 482-488. (in Polish)

44. Cardoso M, Fulton F, Callaghan JP, Johnson M, Albert WJ. A pre/ post evaluation of fatigue, stress and vigilance amongst commercially licensed truck drivers performing a prolonged driving task. Int J Occup Saf Ergo. 2019; 25(3): 344-354.

45. Blower D. Assessment of the effectiveness of advanced collision avoidance technologies. The University of Michigan Transportation Research Institute; Ann Arbor, Michigan, 2014. 